\title{
Possible Effects of the Financial Crisis on Managers' Attitudes to Older Workers
}

I Per Erik Solem

Researcher, Norwegian Social Research (NOVA), Oslo, Norway

\begin{abstract}
The article explores the possible short-term effects of the financial crisis in Norway on cognitive, affective, and behavioral components of managers' attitudes to older workers. The quick shifts in business cycles in 2008 and 2009, i.e., the financial crisis, produced some immediate reactions among managers. In particular, the protection of older workers by downsizing (the seniority principle) gained less support within the first half year of the crisis; however, there was a return to the former level of support within the next half year. This pattern of change was observed in the private sector, while managers in the public sector changed attitudes on a smaller scale and in the direction of increased support for the seniority principle.

The data are from the Nonwegian Senior Policy Barometer where national samples of managers in private companies and in the public sector are interviewed. The study has a time series design with new samples ( $N=750$ ) each year from 2003 to 2011 .

The cognitive component of attitudes was less affected by the financial crisis than the behavioral disposition mentioned above. The tendency was for more positive conceptions of older workers among managers in the public sector. In the private sector, the views of managers changed even less and in the opposite direction.

An impact of more gradual business cycles is seen in the affective component of attitudes. Yet, older workers are among the least popular categories to recruit in both rising and falling cycles.

The finding that managers in the private sector are more affected than managers in the less market-exposed public sector supports the possible effects of the financial crisis on attitudes to older workers. For senior policy, it is notable to keep track of long-term trends and not to be beset by short-term shifts in the need for older workers. Lasting effects of falling business cycles on the employment of older workers may be prevented by reinforcing a solid basis of realistic cognitions about older workers and by openness concerning affective aspects of aging and older workers.
\end{abstract}

\section{KEYWORDS}

Attitudes to older workers / financial crisis / Norway / business cycles / senior policy

\section{Introduction}

he aim of this article is to explore the possible effects of the recent financial crisis in Norway on managers' attitudes to older workers. Norway is among the countries that are the least affected by the international financial crisis, and employment rates following the onset of the crisis in 2008 decreased only in middle-aged and younger

E-mail: pes@nova.no 
groups. However, one possible effect of the crisis is a change in managers' attitudes to marginal groups on the labor market. The demand for labor decreases during downward business cycles. A rational response for employers is to retain the supposedly best workers. Thus, marginal groups may well grow more marginal when business prospects are poor.

The financial crisis in Norway is well suited to explore the possibility that older workers are less attractive on the labor market by economic downturns, even if immediate effects on employment rates are invisible. The suitability of this occasion is due to the abrupt onset of the crisis and, in Norway, the short duration of the crisis. Attitude changes in temporal proximity to the financial fluctuations would probably have some cause-effect connection to the crisis.

Managers' attitudes to older workers are worth exploring because they are expected to influence the employment of older workers. If older workers are seen as obsolete, unable to learn, and to adapt to changes in technology, they are likely not to be recruited, and older employees are likely to be incited to take early pension. This is contrary to political consensus in Norway. Irrespective of short-term fluctuations, the huge demographic changes ahead call for an increasing employment rate at high ages (NOU 2004, Phillipson 2011, Vickerstaff et al. 2007). Because of demographic changes, high costs of future pensions, and lack of labor, older workers are urged-or tempted by incentives - to remain in the labor force at higher ages. The need for older workers to remain in the workforce is a result of two long-term trends in demographics: a rising life expectancy and a declining fertility rate. In the short term, when business cycles are in a downswing, the long-term policies may lose momentum or may be counteracted.

Fluctuations in employment rates are an integrated part of business cycles. Young workers on the edge to entering the labor market are particularly susceptible and unemployment is peaking in young age groups during recessions. As an extreme example, unemployment rates among 16- to 24-year-old Spaniards rose to $51.4 \%$ in December 2011 (Govan 2012). For older workers, unemployment rates are less dramatic. However, in the United States, complaints on age discrimination increased by $29 \%$ from 2007 to 2008 (Ekerdt 2010), which probably is an effect of the financial crisis and the subsequent competition for jobs. Financial crises and recessions are, not surprisingly, affecting the employment situation of workers, including older workers.

In Norway, the gross national product (GNP) was growing from 2002 to the end of 2007 and was ensued by increasing employment (SSB 2012). The number of employed persons started to rise in 2005 and to fall in late 2008. Thus, changes in employment were following the changes in GNP. The fall in the Norwegian GNP started at the turn of the years 2007/2008 in concert with the global financial crisis, which exploded as a media event a little later: September 14, 2008, when the US bank Lehmann Bros. went bankrupt. However, the problems had started earlier, and already in February/March 2007, 25 "sub-prime lenders" who provided loans to high-risk costumers went bankrupt or reported large losses (Cliffe 2010).

The financial crises have had a mild impact in Norway. The short answer of the Financial Crisis Commission as to why Norway was among the countries that have been the least affected by the financial crisis is "a combination of luck, skill and caution" (NOU 2011, p. 240). The luck lies in the oil resources, while the oil revenues 
and the financial institutions are managed with skill and caution. The government revenue from the oil is invested in funds abroad and only a small part $(4 \%)$ is spent in the domestic economy. The so-called $4 \%$-rule is based on a wide political consensus and is only challenged by the right-wing Progress Party. In early 2009, the government injected considerable amounts of money into the economy, e.g., by investing in public buildings. At the same time, large amounts were made available for the banking system. The Norwegian banking system is in international comparison relatively small. In addition, as a consequence of a bank crisis in Norway in the early 1990s, when the government temporarily took over the largest private banks, the Norwegian banking system is more strictly regulated and supervised than what is common internationally (NOU 2011).

The GNP turned upward again by the end of 2009. After a brief period with decreasing employment, the number of employed persons regained an upward drive and in 2010 the number surpassed the level in $2007 / 2008$. Unemployment rates have remained low and fluctuated between $2.5 \%$ and $3.6 \%$ from 2007 up to the present (February 2012: 3.2\%) (SSB 2012).

During the financial crisis, employment rates (the employment/population ratio) of older workers were less affected than the employment rates of younger age groups (StatBank Norway 2012). In the age group 16-24 years, decreases amounted to six to nine percentage points from 2008 to 2011, as compared with a change varying from one percentage point decrease to three percentage points increase in employment rates among seniors (55 years and above). There are many possible reasons for this difference between young and old workers. Employers may have solid positive conceptions of older workers, conceptions that were unaffected by short-term business cycles; they may know their experienced workers and need their expertise. Also, the seniority principle, stating that those hired latest have to go first when it comes to downsizing (Kjeldsberg 2012), may protect the seniors. Dismissal is not a popular step to take, and stopping to recruit new (i.e., young) labor is probably a first step when slimming is necessary. A next step may be the dismissal of young workers. Older workers are most likely the last to be dismissed; however, they may be given offers that are impossible to refuse, such as generous bonus pay if they quit, or a gift pension, or they may be subject to informal pressures and hints concerning retirement, and older workers may accept to stand back in solidarity with young unemployed workers. On the other hand, seniors may cling to their job when times are poor. This is observed as a reaction to the financial crisis in the United States, probably most often when pension schemes were unsound and the pension capital was tied to shares that lost their value due to the crisis (Helman et al. 2009, Munnell et al. 2009).

In Norway, most companies that were affected by the financial crisis probably only reached the step of cutting in the recruitment of young workers. If a more lasting crisis emerges, older workers may be affected more often. The European debt crisis starting in 2009/2010 has so far (early 2012) not affected the GNP or the employment in Norway, but the government warns against it and asks people to be prepared. The degree to which older workers become affected by a stronger and more lasting recession depends, at least partly, on their reputation as workers, in other words, on the attitudes managers have concerning older workers. Effects of the quick shifts in 2008/2009 may reveal effects of business cycles on attitudes toward older workers of relevance also for more long-lasting recession. 


\section{The concept of attitudes}

When analyzing attitudes toward older workers, this study applies the three-component model of attitudes differentiating between the cognitive, affective, and behavioral components (Rosenberg and Hovland 1960). The model is frequently used in recent organizational psychology (Judge and Kammeyer-Mueller 2012) and social gerontology (Coleman and O'Hanlon 2004, Iversen et al. 2009, Tornstam 2011). The alternative unidimensional model defines attitudes by the evaluative or affective component alone (Ajzen 1988). In the unidimensional model, the distinction between attitudes and behavior is clearer, while the three-component model includes opinions in addition to evaluations. Thus, differential effects of cognitions and affect may be distinguished in the three-component model. Efforts to change behavior should take different routes depending on whether the affective or the cognitive component is more strongly involved as the main driver of the unwanted behavior. In the latter case, information campaigns and teaching the correct knowledge, e.g., that older worker at an average perform as well at work as younger workers (Ng and Feldman 2008, Warr 1994), may be effective. If managers just dislike older workers and refuse to recruit older workers for that reason, information campaigns will probably not suffice.

The cognitive component of attitudes consists of opinions, beliefs, and knowledge, as for instance opinions of older workers' health, work performance, learning capacity, and motivation. The affective component surfaces through likes and dislikes, preferences, and feelings for categories of workers. Do older workers elicit positive emotions and attraction or fear, displeasure, or even animosity? The behavioral component contains predispositions to act in certain ways toward older workers, to recruit or to lay off older workers, to offer older workers equal learning opportunities as young workers, or to disregard the learning potential of older workers. These few examples illustrate behavior that has consequences for older workers. However, the behavior itself is not part of the concept of attitudes, and correlations between attitudes and behavior are often less than perfect (Ajzen 2011, La Piere 1934, Stroebe and Jonas 1988).

Because the three components express the same underlying attitude, they are supposed to correlate. However, since the components are different expressions of the attitude, they are expected to correlate only moderately (Stahlberg and Frey 1988). People do not necessarily act according to what they believe in. Managers who believe older workers to have excellent expertise and work performance do not inevitably recruit or retain older workers. The affective component may disturb rational cognitive considerations. A dislike for older persons may supersede managers' beliefs about them. In addition, the behavioral disposition and in the end the behavior are shaped by many other factors than beliefs and feelings about the object, including the age composition of the workforce, a seniority wage system, or high pension costs.

However, there is also a drive toward consistency in attitudes, as in cognitive dissonance reduction, when beliefs about an object are changed according to the behavior performed (Festinger 1957). When a car buyer, who, after many considerations and doubts, eventually decides which car to buy, the tendency is that he, after having made the decision, will conceive the selected car as undoubtedly the best car on the market. Thus, when cognitive dissonance reduction is involved, behavior may reinforce itself and the recruiting of older workers may lead to recruiting more older workers. In addition, recruiting more older workers may come as a result of realizing their real qualities as workers. 
In policy contexts, it is behavior that is the most interesting; what managers do when they are dealing with older workers. This is often not easy to measure directly, as for instance by observation. In surveys, we have to rely on the managers' own words, which behavior they report, and what they intend to do.

Managers' attitudes may affect the workers' decisions about the retirement, if the managers' attitudes are expressed. If the managers express that older workers are appreciated and needed, older workers will probably be more inspired to continue working than if the managers suggest the worker to retire at the earliest occasion. The effect of managers' attitudes is confirmed in numerous studies. In a Swedish survey including both employees and managers in the public sector, managers' attitudes were shown to influence older workers' perception of the work situation and their attitude to extending their working life (Nilsson 2011). It is also shown that an operational senior policy in companies rests on the support from managers at all levels (Steinum 2008, Steinum et al. 2007) and on a trustful relationship between the supervisor and the senior worker (Furunes and Mykletun 2010). Probably, an operational senior policy and a trustful relationship facilitate the expression of positive attitudes to older workers. In addition, senior policy measures may in their own right convey an intention of the management to retain older workers, irrespective of the content of the measures offered (Hilsen and Salomon 2010). It is essential for the preference of early or late exit that the older workers feel that the company wants them. The supervisor is central in conveying the attitudes of the company and is found to influence retirement decisions strongly (Hilsen and Steinum 2006, Huuhtanen and Piispa 1999, Midtsundstad 2006).

\section{Methods}

The data are from the Norwegian Senior Policy Barometer for managers collected every year from 2003 to 2011. Data are gathered on national samples ( $N=$ about 750 each year) by the market research institute MMI/Synovate for the Centre for Senior Policy. Computer-assisted telephone interviews (CATI) were used and the period for the data collection was early September each year. The samples consist of top managers or their deputies from a representative sample of 600 private sector companies with more than 10 employees and a representative sample of 150 managers or deputies from the public sector. Sampling procedures and frequency tables are presented in a field report (Dalen 2011). The study has a time series design and is not a panel study. Thus, individual changes among managers are not observed in this study, only changes at the aggregate level.

Changes from September 2008 to September 2011 are compared with changes from 2003 to 2008, i.e., after and before the financial crisis exploded as a media event on September 14, 2008. In particular, changes from 2008 to 2009 indicate effects of the financial crisis. In addition to the annual data collection, comparable data are collected on two of the attitude dimensions in February 2009, when managers were sampled by the same procedures as the annual September samples (Lillebø 2009). Thus, the immediate effects of the financial crisis from September 2008 to February 2009 are possible to discern from more durable effects to September 2009 and to 2010 and 2011. However, the data do not permit to rule out other possible causes of changes in attitudes, e.g., 
information campaigns on senior workers and public debates on pension reforms. Nevertheless, other events than the financial crisis are unlikely to have operated in the same limited time period. In addition, the public awareness over the last decade has promoted the employment of senior workers. Thus, the effects of the public awareness on attitudes would above all be expected to have a positive direction.

The descriptive statistics of 'crosstabs' in SPSS version 19 are used. Differences between observation times are tested by Pearson chi-square using a two-sided significance level set at $p<0.05$. Since the sample of public sector managers is substantially smaller than the sample of private sector managers, changes among public sector managers have to be larger to reach statistical significance.

\section{Measures}

Opinions (cognitive component):

- Workers 50 years and above have just as good work performance as those below 50 (strongly agree/partly agree/neither agree nor disagree/partly disagree/strongly disagree)

Preferences (affective component):

- How well or poorly would you like to recruit the following types of workers? (very well, fairly well, neither well nor poorly/somewhat poorly/very poorly)

Seniors, Older workers, Young workers, Experienced workers, Workers with fresh education.

For 2007-2011, also immigrant workers and functionally disabled workers were included in the question.

Unfortunately, the February 2009 data collection does not include a question on the affective component of attitudes to older workers. Thus, differential immediate effects on the affective component are impossible to detect in this data set. Analyses of changes in preferences are included to describe a possible connection to changes in business cycles in a more long-term perspective than six to twelve months.

Behavior potential (behavioral component):

- When a company has to downsize, it should be possible to fire older workers before younger workers (strongly agree/partly agree/neither agree nor disagree/partly disagree/strongly disagree)

As part of the concept of attitudes, this question measures not behavior, but behavior potential. It is also a rather indirect measure of behavior potential, since behavior in accordance with this view is contrary to broadly accepted conventions in Norwegian working life (Kjeldsberg 2012). A more direct question on the managers' behavioral intentions may have come nearer to actual behavior, but still without measuring behavior directly, and the answers would still be influenced by social desirability. Within the short time limits of this study due to the acute onset and short duration of the financial crisis in Norway, behavior changes in actual recruitment of senior workers or in firing seniors would be hard to detect other than in big companies with a sufficiently large turnover. 


\section{Results}

\section{The cognitive component}

Managers in both the private and the public sector hold positive views on the work performance of senior workers (50 years and over), as a clear majority strongly agree that workers 50 years and above perform just as well at work as younger workers (figure 1).

The results show only small changes in this cognitive attitude component, and no significant acute reaction to the financial crisis in 2008 and 2009. However, public sector managers are growing more positive from 2007 (72\%) to $2011(87 \%)(p<0.05)$, while private sector managers only grow more positive from $2006(69 \%)$ to $2007(76 \%)$ $(p<0.05)$. From 2007 to 2010 , there was a small, but steady and statistically significant $(p<0.05)$ decrease in the proportion who strongly agreed that workers 50 years and over perform as well as younger workers. Thus, there is a possible negative effect of the financial crisis on private sector managers' view on senior workers. The negative effects are particularly seen in the commodity trade, the hospitality industry (hotels and restaurants), and in the transportation and communication industries, while changes are smaller in manufacturing, construction, and service industries (Solem 2010). The first three, the commodity, hospitality, and transportation/communication industries, seem more youth oriented and the managers may have less firm convictions on the equally good work performance of older workers compared with younger workers. Negative shifts in business cycles may more easily disturb the positive view of older workers in the more youth-oriented industries. However, the possible effects of the financial crisis are, as measured here, not strong, and the majority of managers still hold a relatively steady and positive cognitive conception of older workers.

Figure I: Proportion of managers in private and public sector who "strongly agree" that workers 50 years and above have just as good work performance as those below 50 .

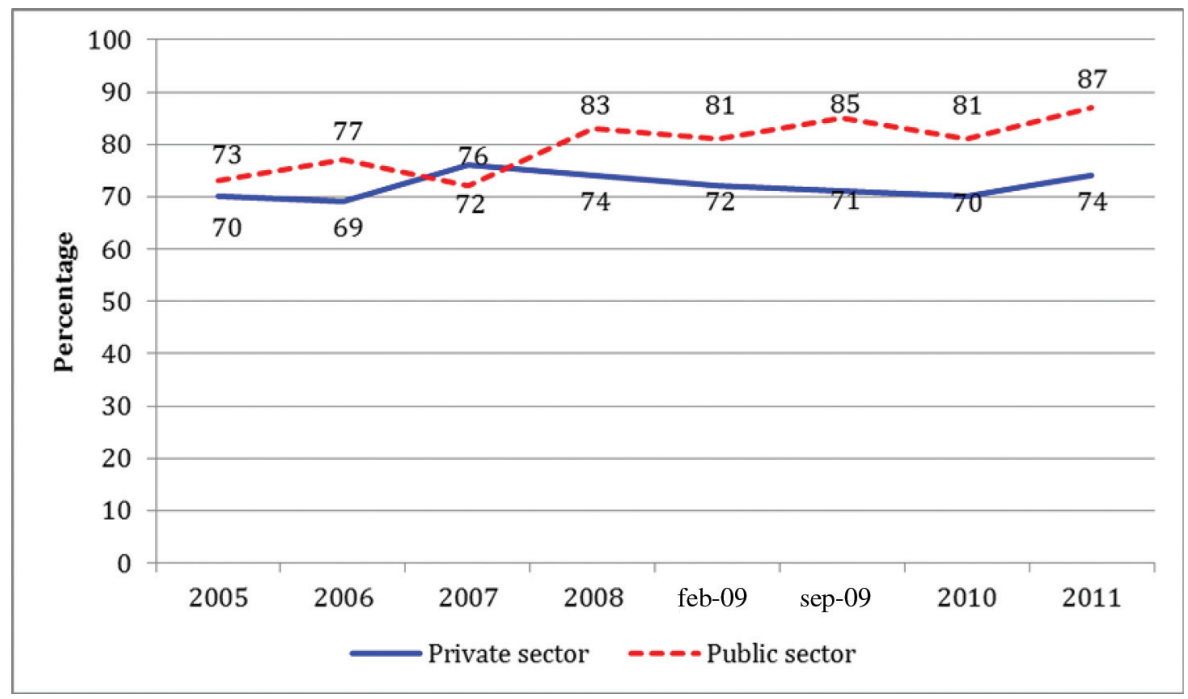


The opposite effect in the public sector may reflect the less exposure to business cycles and to the market situation in this sector. The trend in positive direction among managers in the public sector must have additional reasons, like for instance that more managers in the public sector realize that they, due to demographic changes, shall need a growing number of older workers in the years to come. The private sector is more sensitive to business cycles, and managers probably have more acute needs to control the size of the workforce. In this way, the financial crisis may have had an effect on the differences between the views of private and public sector managers since 2008. Yet again, there are no strong effects on how older workers' performance is viewed.

\section{The affective component}

The affective attitude component as measured by managers' preferences for different categories of workers shows a clear first preference for "experienced workers." Managers both in the public and private sector first of all "like to" recruit experienced workers. The experienced workers that managers have in mind are probably not very old. "Seniors" and "older workers" are in the Senior Policy Barometer as an average conceived of as above 55 years of age (Dalen 2011), and they are far less attractive than the "experienced workers." Experience does not seem to be very closely associated with age, at least when it comes to ages above 55 years. A study by Larsen (1991) indicates that a majority of managers consider applicants to have sufficient experience at about 35 years of age.

Next to experienced workers, managers like to hire young workers. Senior workers and older workers are the least preferred of the categories included in figure 2. From $2004 / 2005$, there was a steady and significant increase in managers' interest in hiring

Figure 2: Proportion of managers who very well would like to recruit various groups of workers.

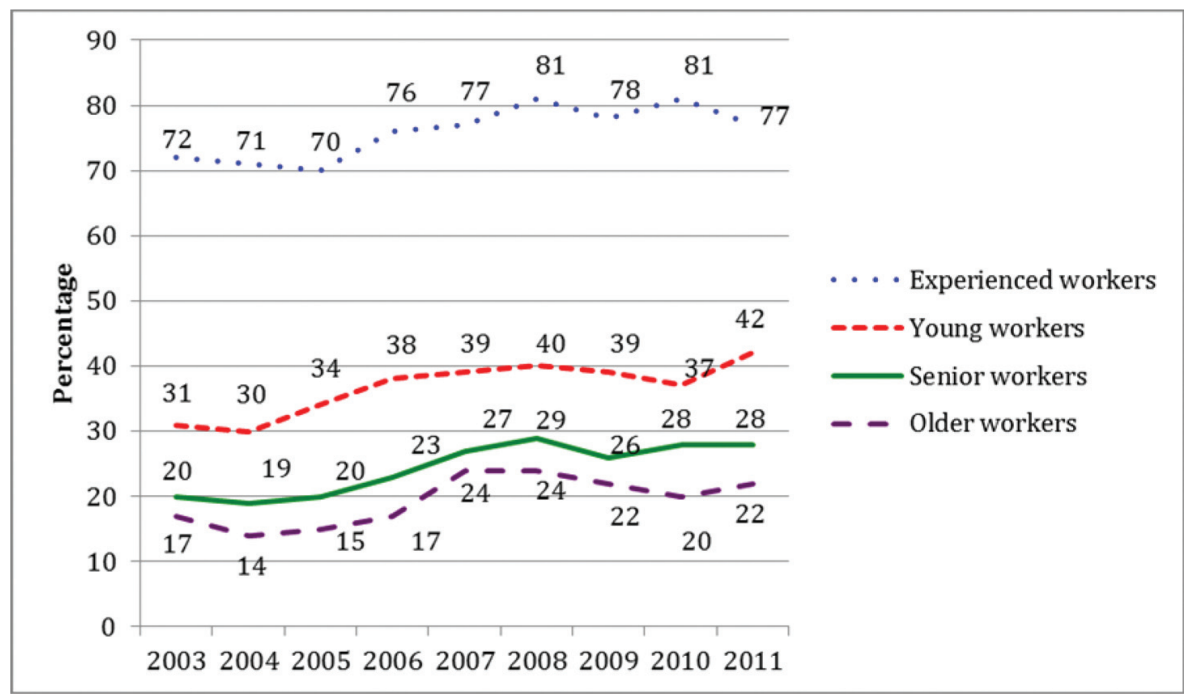


all the types of workers included in the question. The pattern is roughly the same in the public and the private sector. Like the other groups, older workers and seniors have become more attractive up to 2008 , probably as a consequence of upward business cycles and a general increase in the demand for labor. The increase in interest for recruiting workers levels off from 2008, which probably is a consequence of the financial crisis. Unfortunately, on this question there is no available observation in February 2009, and an acute reduction in the interest for older workers and seniors may have taken place. This we do not know. However, the annual observations confirm that managers' willingness to recruit workers is connected to business cycles, and that business cycles seem to hit all the categories of workers included in the question. There is no indication that seniors or older workers are hit any harder than the other categories. The liking of various categories of workers seems to be steady when it comes to rank order. Managers prefer the experienced ones best and then the young workers. Next come workers with fresh education, who are not included in figure 2, but follow the same pattern from 2003 to 2011 as the other categories (Dalen 2011).

For comparison, two other marginal categories of workers, "immigrant workers" and "functionally disabled workers," were included in the question in 2008. The popularity of immigrant workers is at the same level as older workers and senior workers, while functionally disabled workers are the least preferred. In 2011, 15\% of the managers would very much like to recruit disabled workers compared with $22 \%$ who would very much like to recruit older workers. The two least popular groups of workers, the older workers and the functionally disabled workers, are both more attractive for managers in the public sector than in the private sector (Dalen 2011). This may reflect a situation on the labor market in Norway, with lack of labor in many occupations. Workers may pick among the better-paid jobs, which often are in the private sector. As a result, the public sector may have to recruit workers from a broader range. Higher unemployment rates might change this situation in a way that would make it more tempting for managers also in the public sector to pick workers from the more attractive categories, leaving older workers and the functionally disabled with less job opportunities. However, the financial crisis and falling business cycles have not yet been of a magnitude in Norway that makes such effects observable.

\section{The behavioral component}

The question carrying the behavioral attitude component concerns dismissal of workers in the case of downsizing. In recession, downsizing is one possible strategy to handle the problems or it is simply a reaction to diminishing returns. When the market demands less of the goods or services a company produces, less has to be produced, and fewer workers are needed. The difficult question of who to dismiss emerges. Seniority rules tend to protect workers with long tenure in the firm; in practice, this most often means older workers. Companies would for economic reasons be expected to prefer to retain the most productive workers. If older workers are considered to be less productive, managers may feel that the seniority principle is restraining their opportunity to retain the best workers. In times of recession, managers may be particularly bothered by such restrictions. As public services are less affected by the market situation and by business cycles, managers in the public sector are expected to be less disturbed by the seniority principle. 
Figure 3: Proportion of managers in private and public sector who strongly disagree that when a company has to downsize, it should be possible to dismiss older workers before younger workers.

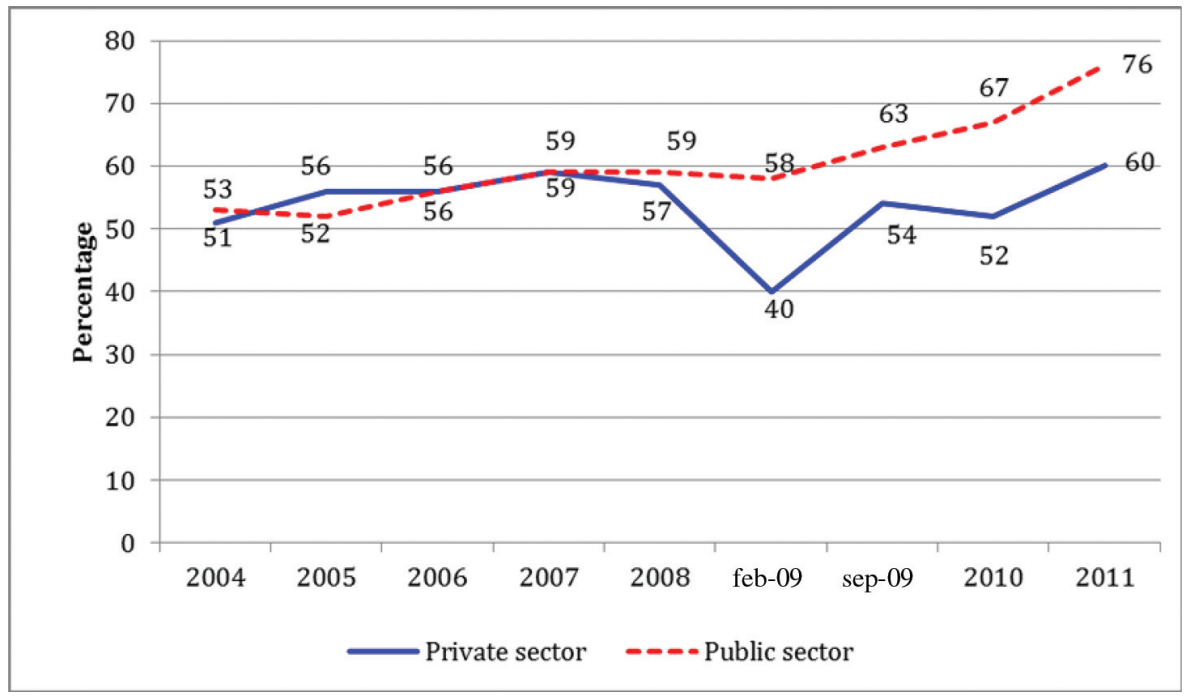

The results shown in figure 3 demonstrate a clearly different pattern in the private and public sector from 2008. The financial crisis did not seem to bother managers in the public sector. On the contrary, an increasing proportion of public sector managers tend to disagree that it should be possible to dismiss older workers before younger workers. This indicates an increasing support for the seniority principle by downsizing. The rise is of a considerable size, from 59\% who strongly disagree in 2008 to $76 \%$ in 2011 $(p<0.05)$. Managers in the public sector seem to be increasingly protective of older workers, perhaps because they realize that demographic changes will urge them to retain as many older workers as they can.

Among managers in the private sector, we see a temporary dramatic change. In February 2009 , the private managers no longer disagreed to the same extent as before, they seemed less protective of older workers. But only six months later, they have changed back. Both changes, from $57 \%$ who disagree in 2008 to $40 \%$ in February 2009, and from February 2009 to $54 \%$ in September 2009, are highly significant $(p<0.001)$. The reaction, probably due to the financial crisis, was so acute that observations one year apart (2008 and 2009) would not have detected any significant changes.

From September 2009, managers in the private sector are back at the same level of disagreement with the option of dismissing older workers before younger workers, and from 2010 to 2011 this protective attitude toward older workers shows an increasing support, from $52 \%$ to $60 \%(p<0.01)$, who strongly disagree to dismiss older workers before younger workers. As times look better, there seems to be less need to challenge the seniority principle.

Within the private sector, the same pattern of a large reduction in the proportion that strongly disagree from September 2008 to February 2009 and a rapid recovery to 
September 2009 is seen in all industries. A strong reaction from managers is seen particularly in the commodity trade, the hospitality industry, and the transport and communication industry. In none of the three branches of the public sector (administration, education, and health and social services), any such reaction is observed.

\section{Discussion}

The results indicate that the financial crisis has had an immediate effect making private sector managers temporarily less protective of older workers when there is a need for downsizing. Three observations of managers' attitudes over a twelve-month periodearly September 2008 (just before the financial crisis "exploded" in mass media), late February 2009, and early September 2009-demonstrate the strong short-term reactions. The behavioral disposition of accepting the dismissal of older workers before younger workers in the case of downsizing gains considerably less opposition among managers in the private sector in February 2009 than in September 2008 and is back to the previous level in September 2009.

The results also indicate that more gradual business cycles have effects both on managers' opinions (the cognitive element of attitudes) and preferences (the affective element) concerning older workers. Effects are clearer in the private sector than in the public sector. This is expected since the private sector is more directly influenced by economic cycles.

Conceptions of the work performance of older workers compared with younger workers do not show the same immediate changes as the behavioral dispositions. We find a positive shift in managers' opinion of older workers' work performance from 2007 to 2008 in the public sector and the opposite tendency among managers in the private sector from 2007 to 2010. In both cases, the changes are less dramatic compared with the changes in the behavioral dispositions mentioned above. Thus, the cognitive content of attitudes toward older workers seems to change more slowly than the behavioral dispositions. Yet, it is not possible to establish from the data of the Norwegian Senior Policy Barometer if behavior itself changes at the same pace as behavioral dispositions. The finding that the behavioral disposition concerning the seniority principle changes back to normal quite fast may indicate that the behavior has been less affected. The relatively stable positive opinion about older workers' performance may have acted as a buffer facilitating a quick return of behavioral dispositions back to the previous level.

Also the affective component of attitudes, as measured by managers' liking for various categories of workers, follows changes in business cycles over the period from 2003 to 2011. However, the changes in the affective component do not hit seniors or older workers in particular. The changes seem to reflect a general fluctuation in the demand for labor. A low preference for seniors and older workers is stable in the sense that the rank order of older categories is not only far behind "experienced workers" in particular but also steadily behind "young workers." Young experienced workers seem to be an ideal throughout changing business cycles. The affective component of attitudes toward older workers is obviously more negative than the cognitive component.

The behavioral dispositions of managers to retain older workers seem to change more easily than their opinions of older workers. Stable positive conceptions of older workers may be a solid foundation that is able to bring negative fluctuations in 
behavioral dispositions back in a positive direction. If this is the case, it is important to reinforce realistic conceptions of older workers and to endorse solid knowledge about advantages and disadvantages of older workers. Because cultural attitudes about ageing and older persons are basically negative (Levy 2003), realistic information may sound as exaggerations of positive aspects. Studies on older workers' performance conclude mainly in positive ways ( $\mathrm{Ng}$ and Feldman 2008). Thus, to inform realistically about older workers, positive aspects may have to be accentuated. However, some aspects are negative. In occupations where short reaction time and physical power are required, most older workers are at a disadvantage, while in occupations that emphasize experience and expertise, many older workers have an advantage (Warr 1994).

Since the affective component of attitudes toward older workers seems more negative than the cognitive component, affects elicited by older workers may need more attention to achieve behavioral changes among managers. Dialogues and reflections about affective aspects of aging and older workers may encourage managers, seniors, and colleagues to react with less automatic reflexes based upon built-in negative cultural attitudes. However, business cycles and the need for labor represent crucial conditions for the employment of older workers as well as of other categories of workers. In a short range, young workers on the edge of entering the labor market are more vulnerable than older workers already gainfully employed. In a long range, older workers are also at risk because they are among the least attractive groups for managers to recruit.

\section{References}

Ajzen, I. (1988) Attitude, personality and behavior. Milton Keynes: Open University Press.

Ajzen, I. (2011) 'Job satisfaction, effort, and performance: a reasoned action perspective', Contemporary Economics 5(4): 32-43.

Cliffe, M. (2010) 'Working conditions and early retirement: a prospective study of retirement behavior', Research on Aging 27(1): 3-30.

Coleman, P. G. and O'Hanlon, A. (2004) Ageing and development. Theories and research. London: Arnold Publishers.

Dalen, E. (2011) Norsk seniorpolitisk barometer 2011. Ledere i arbeidslivet (The Norwegian Senior Policy Barometer. Leaders in working life). Oslo: Synovate 2011.

Ekerdt, D. J. (2010) 'Frontiers of research on work and retirement', Journal of Gerontology: Social Sciences 65B(1): 69-80.

Festinger, L. (1957) A theory of cognitive dissonance. Stanford: Stanford University Press.

Furunes, T. and Mykletun, R.J. (2010) Tid for lederskap. En oppsummering av forskning om aldersriktig ledelse 2007-2010 (Time for leadership. A review of research on age mannagement). Stavanger: Universitet i Stavanger. [Online] URL: http://www.seniorpolitikk. no (14.3.2012).

Govan, F. (2012) Spain's lost generation: youth unemployment surges 50 per cent [online] URL: http://www.telegraph.co.uk/news/worldnews/europe/spain/9044897/Spains-lostgeneration-youth-unemployment-surges-above-50-per-cent.html (10.5.2012).

Helman, R., Copeland, C. and VanDerhei, J. (2009) 'The 2009 Retirement Confidence Survey: economic drives confidence to record lows; many looking to work longer', EBRI Issues Brief, no 328, April 2009.

Hilsen, A. I. and Salomon, R. (2010) Seniorpolitikk—virker virkemidlene? (Senior policy-do the measures work?). AFI-rapport 4/2010. Oslo: Arbeidsforskningsinstituttet. 
Hilsen, A. I. and Steinum, T. (2006) Fortell meg at jeg er ønsket. Sluttrapport fra Livsfaseprosjektet $i$ trygdeetaten, et prosjekt under Nasjonalt krafttak for seniorpolitikk $i$ arbeidslivet. (Tell me that I am needed. Final report from the Life Phase Project in the Social Security Service, a project under the National Initiative for Senior Policy in Working Life). Oslo: Arbeidsforskningsinstituttet.

Huuhtanen, P. and Piispa, M. (1999) 'Attitudes towards early retirement and work', in Ilmarinen, J. and Louhevaara, V. (eds.) FinnAge-Respect for the aging: Action programme to promote health, work ability and wellbeing of aging workers 1990-96 (19-30). Research Reports 26. Helsinki: Finnish Institute of Occupational Health.

Iversen, T. N., Larsen, L. and Solem, P. E. (2009) 'A conceptual analysis of ageism', Nordic Psychology 61(3): 4-22.

Judge, T. A. and Kammeyer-Mueller, J. D. (2012) 'Job attitudes', Annual Review of Psycho$\log y$ 63: 341-347.

Kjeldsberg, C. F. (2012) Oppsigelse av arbeidsforhold (Dismissal of employees) [online], URL: www.jusstorget.no/article. $a s p$ ? Key=1\&FagKey=3\&ArtKey=161) (10.5.2012).

La Piere, R. T. (1934) 'Attitudes versus actions', Social Forces 13: 230-237.

Larsen, K. A. (1991) Fremtidens arbeidsmarked (The future labor market). ECON-rapport nr. 19/91. Oslo: ECON senter for økonomisk analyse.

Levy, B. (2003) 'Mind matters: Cognitive and physical effects of aging self-stereotypes', Journal of Gerontology: Psychological Sciences 57B: P409-P417.

Lillebø, K. (2009) Holdninger til seniorer. En undersøkelse blant ledere 23-27 februar 2009 (Attitudes toward seniors. A survey among managers 23-27. February 2009). Oslo: Synovate.

Midtsundstad, T. (2006) Hvordan bidra til lengre yrkeskarrierer? Erfaringer fra norsk og internasjonal forskning om tidligpensjonering og seniortiltak (How to contribute to prolonged working careers? Experiences from Norwegian and international research on early exit and senior policy). Oslo: Fafo rapport 534.

Munnell, A. H., Muldoon, D. and Sass, S. A. (2009) 'Recession and older workers', Issue in Brief, January 2009, no 9-2. Center for Retirement Research Boston College.

Ng, T.W.H. and Feldman, D. C. (2008) 'The relationship of age to ten dimensions of job performance', Journal of Applied Psychology 93: 392-423.

Nilsson, K. (2011) 'Attitudes of managers and older employees to each other and the effects on the decisions to extend working life', in Ennals, R. and Salomon, R.H. (eds.) Older workers in a sustainable society (147-156). Frankfurt am Main: Peter Lang Verlag.

NOU 2004:1. Modernisert folketrygd. Barekraftig pensjon for framtida (A modern social security system. Sustainable pension for the future). Oslo: Statens forvaltningstjeneste.

NOU 2011:1. Bedre rustet mot finanskriser. Finansutvalgets utredning (Improved preperation for financial crises. The report from the Financal Crisis Commission). Oslo: Departementenes servicesenter. (English summary: 239-251).

Phillipson, C. (2011) 'Extending working life and re-defining retirement: Problems and challenges for social policy', in Ennals, R. and Salomon, R. H. (eds.) Older workers in a sustainable society (233-243). Frankfurt am Main: Peter Lang Verlag.

Rosenberg, M. J. and Hovland, C. I. (1960) 'Cognitive, affective, and behavioral components of attitudes', in C. I. Hovland and M. J. Rosenberg (eds.) Attitude organization and change (1-14). New Haven: Yale University Press.

Solem, P. E. (2010) Eldres posisjon i arbeidslivet ved konjunkturomslag (Older workers' position in working life when business cycles turn). Rapport nr. 5/10. Oslo: Norsk institutt for forskning om oppvekst, velferd og aldring.

SSB (2012) Konjunkturer-statistikk, analyser og prognoser (Business cycles-statistics, analyzes and prognoses [online], URL: www.ssb.no/okind/fig/fig.html) (15.2. 2012). 
Stahlberg, D. and Frey, D. (1988) 'Attitudes I: Structure, measurement and functions', in Hewstone, M., Stroebe, W., Codol, J-P. and Stephenson, G. M. (eds.) Introduction to Social Psychology (142-166). Oxford: Basil Blackwell.

StatBank Norway (2012) [online], URL: statbank.ssb.no//statistikkbanken. Tabell 03781. (15.2.2012).

Steinum, T. (2008) Hva kan vi laere av gode eksempler på seniorpolitikk? (What can we learn from good examples of senior policy?). Oslo: Arbeidsforskningsinstituttet.

Steinum, T., Hilsen, A. H. and Bull, H. (2007) Kunnskapsstatus for programmet FARVE (forsøksmidler arbeid og velferd). Tema: $\AA$ øke den giennomsnittlige avgangsalderen. (State of the art for the program FARVE (Innovations in work and welfare). Subject: To increase the average age of exit). AFI-notat 10/2007. Oslo: Arbeidsforskningsinstituttet.

Stroebe, W. and Jonas, K. (1988) 'Attitudes II: Strategies of attitude change', in Hewstone, M., Stroebe, W., Codol, J-P. and Stephenson, G. M. (eds.) Introduction to Social Psychology (167-196). Oxford: Basil Blackwell.

Tornstam, L. (2011) Åldrandets socialpsykologi, Åttonde upplagan. (The social psychology of aging. 8th edition). Stockholm: Norstedts Akademiska Förlag.

Vickerstaff, S., Loretto, W. and White, P. (2007) 'The future for older workers: opportunities and constraints', in Loretto, W., Vickerstaff, S. and White, P. (eds.) The future for older workers. New perspectives (203-226). Bristol: The Policy Press.

Warr, P. (1994) 'Age and job performance', in Snel, J. and Cremer, R. (eds.) Work and aging: A European perspective. London: Taylor \& Francis. 